\title{
CAMP-ACTIVATED CHLORIDE CURRENTS IN AMPHIBIAN RETINAL PIGMENT EPITHELIAL CELLS
}

\author{
BY BRET A. HUGHES AND YASUNORI SEGAWA \\ From the Departments of Ophthalmology and Physiology, University of Michigan, \\ Ann Arbor, MI 48105, USA
}

(Received 25 August 1992)

\section{SUMMARY}

1. The effect of cAMP on whole-cell currents in isolated retinal pigment epithelial (RPE) cells of the bullfrog and marine toad was investigated by means of the perforated patch clamp technique.

2. Superfusing cells with either cAMP or forskolin led to the development of a time-independent current that had a linear current-voltage $(I-V)$ relationship. The reversal potential of $\left(V_{\text {rev }}\right)$ of the cAMP-activated current was unaffected by the removal of either $\mathrm{Na}^{+}$or $\mathrm{HCO}_{3}{ }^{-}$from the external and internal solutions or by the addition of extracellular barium, but it was near the $\mathrm{Cl}^{-}$equilibrium potential $\left(E_{\mathrm{Cl}}\right)$ over a wide range of extracellular $\mathrm{Cl}^{-}$concentrations, suggesting the presence of a $\mathrm{Cl}^{-}$-selective channel.

3. The anion permeability sequence of the cAMP-activated conductance calculated from biionic reversal potentials was $\mathrm{NO}_{3}^{-}=\mathrm{I}^{-}>\mathrm{Br}^{-}>\mathrm{Cl}^{-} \gg \mathrm{HCO}_{3}^{-}>$ methanesulphonate.

4. The conductance was blocked by a variety of $\mathrm{Cl}^{-}$transport inhibitors, including 4,4'-diisothiocyanatostilbene-2,2' ${ }^{\prime}$-disulphonic acid (DIDS), 4,4'-dinitro-2, $2^{\prime}$-stilbene disulphonic acid (DNDS), frusemide, $N$-phenylanthranilic acid (DPC) and niflumic acid.

5. The present study demonstrates that cAMP activates a $\mathrm{Cl}^{-}$-selective channel that most probably resides in the basolateral membrane.

\section{INTRODUCTION}

The retinal pigment epithelial (RPE) is a simple cuboidal epithelium that separates the distal retina from its major blood supply in the choroid. Its apical membrane is highly elaborated, forming villus-like processes that are closely apposed to the outer segments of rod and cone photoreceptors. One of the principal functions of the RPE is to control the ionic composition and volume of the extracellular fluid that surrounds the photoreceptor outer segments. Radioisotope flux measurements in the short-circuit state have established that the RPE actively transports $\mathrm{Cl}^{-}, \mathrm{HCO}_{3}^{-}$, and $\mathrm{K}^{+}$in the retina-to-choroid (absorptive) direction, and $\mathrm{Na}^{+}$in the choroid-toretina direction (Miller \& Steinberg, 1977; Miller \& Farber, 1984; Miller \& Edelman, 1990). However, in the open-circuit state, the apical-positive transepithelial potential 
drives net $\mathrm{Na}^{+}$movement in the absorptive direction through the paracellular pathway, which has a relatively high $\mathrm{Na}^{+}$permeability (Hughes, Miller \& Machen, 1984; Hughes, Miller \& Farber, 1987). This net ion absorption provides the driving force for fluid reabsorption, which is an important factor in maintaining retinal adhesion (Marmor, 1989).

Previous studies on the isolated RPE-choroid preparation of the bullfrog demonstrated that cAMP inhibits active $\mathrm{Cl}^{-}$absorption and stimulates active $\mathrm{Na}^{+}$ secretion, leading to the inhibition of fluid absorption (Miller \& Farber, 1984; Hughes et al., 1984, 1987). Preceding these steady-state changes in fluid and ion fluxes is a complex series of voltage changes that take place across the apical and basolateral membranes (Hughes, Miller, Joseph \& Edelman, 1988) and which begin with a depolarization of the basolateral membrane potential. Although the origin of the basolateral membrane depolarization has not been identified, there is electrophysiological evidence that it is associated with an increase in the conductance of that membrane (Hughes et al. 1988). These results suggested the possibility that the basolateral membrane depolarization arises from the activation by cAMP of a conductance for an ion, such as $\mathrm{Na}^{+}$or $\mathrm{Cl}^{-}$, whose reversal potential is positive to the resting membrane potential. Alternatively, cAMP might change the intracellular activity of a permeant ion by modulating its transport into or out of the cell via a co-transporter or exchanger, which in turn could alter both the equilibrium potential and conductance for the ion. Intracellular recordings with single-barrelled $\mathrm{Cl}^{-}$selective microelectrodes demonstrated that cAMP causes the intracellular $\mathrm{Cl}^{-}$ activity to decrease (B. A. Hughes \& S. S. Miller, unpublished observations), consistent with an increase in basolateral membrane $\mathrm{Cl}^{-}$conductance. However, the observed decrease in intracellular $\mathrm{Cl}^{-}$activity could also result from the inhibition of active transport of $\mathrm{Cl}^{-}$into the cell, for example, by the apical membrane $\mathrm{Na}^{+}-\mathrm{K}^{+}-2 \mathrm{Cl}^{-}$co-transporter (Adorante \& Miller, 1990; Kennedy, 1990; la Cour, 1992).

The purpose of this study was to characterize the cAMP-activated conductance in terms of voltage sensitivity, ion selectivity, and pharmacological sensitivity using the perforated patch configuration of the patch clamp technique (Horn \& Marty, 1988). We provide evidence that cAMP activates a $\mathrm{Cl}^{-}$-selective channel. Preliminary accounts of this work have been reported in abstract form (Hughes \& Paterson, 1991; Hughes \& Segawa, 1992).

\section{METHODS}

\section{Solutions}

The composition of the bathing solutions is given in Table 1. Normal and $0 \mathrm{Na}^{+}-\mathrm{HCO}_{3}^{-}$-buffered external solutions were equilibrated with $95 \%$ air $-5 \% \mathrm{CO}_{2}$ and had a $\mathrm{pH}$ of $7 \cdot 4$, whereas the $0 \mathrm{Na}^{+}$-high $\mathrm{HCO}_{3}{ }^{-}$solution was equilibrated with $87 \%$ air-13\% $\mathrm{CO}_{2}$ and had a $\mathrm{pH}$ of 7.6. All Hepes-buffered solutions were equilibrated with room air and had a $\mathrm{pH}$ of $7 \cdot 4.0 \mathrm{Na}^{+} \mathrm{Ringer}$ solution was formulated by substituting $\mathrm{NaCl}$ and $\mathrm{NaHCO}_{3}$ (or Hepes- $\mathrm{NaOH}$ ) with the appropriate salt of $\mathrm{N}$-methyl-D-glucamine (NMDG). In $\mathrm{Cl}^{-}$substitution experiments, $\mathrm{NaCl}$ in the bath solution was replaced by either $\mathrm{NaI}, \mathrm{NaBr}, \mathrm{NaNO}_{3}$, or sodium methanesulphonate. The osmolalities of all external solutions were $230 \pm 10$ mosmol $\mathrm{kg}^{-1}$.

Pipettes were generally filled with an internal solution containing the same buffer as that in the external solution. In most experiments involving external solutions buffered with $\mathrm{HCO}_{3}{ }^{-}-\mathrm{CO}_{2}$, the internal solution consisted of (mM): $25 \mathrm{KCl}, 66$ potassium gluconate, $17 \mathrm{KHCO}_{3}, 5.5 \mathrm{EGTA}-\mathrm{KOH}$, $0.5 \mathrm{CaCl}_{2}$, and $2.0 \mathrm{MgCl}_{2}$. When equilibrated with $95 \%$ air $-5 \% \mathrm{CO}_{2}$, this solution had a $\mathrm{pH}$ of 
$7 \cdot 2 \pm 0 \cdot 05$. The Hepes-buffered internal solution contained $(\mathrm{mm}): 72$ potassium gluconate, $25 \mathrm{KCl}$, 10 Hepes-KOH, 5.5 EGTA, $0.5 \mathrm{CaCl}_{2}, 2 \mathrm{MgCl}_{2}$, and had a $\mathrm{pH}$ of $7.2 \pm 0.05$. The osmolalities of all internal solutions were $220 \pm 10 \mathrm{mosmol} \mathrm{kg}{ }^{-1}$. 4,4'-Dinitro-2,2'-stilbene disulphonic acid (DNDS) was obtained from Pfaltz and Bauer, Inc. (Waterbury, CT, USA), and $N$-phenylanthranilic acid (DPC) from Aldrich Chemical Co. (Milwaukee, WI, USA). Al other chemicals were obtained from Sigma Chemical Co. (St Louis, MO, USA).

TABLE 1. Composition of bathing solutions (mM)

\begin{tabular}{|c|c|c|c|c|c|c|}
\hline & $\begin{array}{c}\text { Normal } \\
\text { Hepes }\end{array}$ & $\underset{\mathrm{HCO}_{3}^{-}}{\text {Normal }}$ & $\begin{array}{l}0 \mathrm{Na}^{+}- \\
\mathrm{Hepes}\end{array}$ & $\begin{array}{l}0 \mathrm{Na}^{+}- \\
\mathrm{HCO}_{3}^{-}\end{array}$ & $\begin{array}{c}\mathrm{O} \mathrm{Na}^{+}- \\
\text {high } \mathrm{HCO}_{3}^{-}\end{array}$ & $\mathbf{X}^{-}$ \\
\hline $\mathrm{NaCl}$ & 110 & $82 \cdot 5$ & - & - & - & - \\
\hline $\mathrm{KCl}$ & 2 & 2 & 2 & 2 & 2 & - \\
\hline Hepes & 5 & - & 5 & - & - & 5 \\
\hline $\mathrm{NaHCO}_{3}$ & 一 & $27 \cdot 5$ & - & - & 一 & - \\
\hline Glucose & 10 & 10 & 10 & 10 & 10 & 10 \\
\hline $\mathrm{CaCl}_{2}$ & $1 \cdot 8$ & $1 \cdot 8$ & $1 \cdot 8$ & $1 \cdot 8$ & $1 \cdot 8$ & - \\
\hline $\mathrm{MgCl}_{2}$ & 1 & 1 & 1 & 1 & 1 & - \\
\hline $\mathrm{CaMeSO}_{3}$ & - & 一 & 一 & 一 & - & $1 \cdot 8$ \\
\hline $\mathrm{MgMeSO}_{3}$ & - & - & 一 & - & - & 1 \\
\hline $\mathrm{NMDG}-\mathrm{HCO}_{3}$ & - & - & - & $27 \cdot 5$ & 110 & - \\
\hline NMDG-Cl & - & - & 110 & $82 \cdot 5$ & - & - \\
\hline $\mathrm{NaX}$ & - & - & - & - & - & 30 \\
\hline $\mathrm{KMeSO}_{3}$ & - & - & - & - & - & 2 \\
\hline $\mathrm{NaMeSO}_{3}$ & - & - & - & - & - & 80 \\
\hline
\end{tabular}

The $\mathrm{pH}$ of all solutions was titrated to $7 \cdot 4$ with $\mathrm{NaOH}$ (or with NMDG free base for $0 \mathrm{Na}^{+}$ solutions). The symbol X- stands for $\mathrm{Cl}^{-}, \mathrm{I}^{-}, \mathrm{Br}^{-}, \mathrm{NO}_{3}{ }^{-}$or methanesulphonate $\left(\mathrm{MeSO}_{3}\right)$. Solutions buffered with $\mathrm{HCO}_{3}{ }^{-}$were equilibrated with $5 \% \mathrm{CO}_{2}$, balance air, and those buffered with Hepes were equilibrated with air.

\section{Cell isolation}

Medium-sized bullfrogs (Rana catesbeiana) or marine toads (Bufo marinus) were kept for 1 week or longer in running tap water on a cycle of $9 \mathrm{~h}$ light-15 $\mathrm{h}$ dark and fed live crickets once a week. Bullfrogs or toads were dark adapted for at least $4 \mathrm{~h}$ before being killed by decapitation and pithed. The RPE-choroid was dissected from the sensory retina and sclera under dim-red light as previously described (Miller \& Steinberg, 1977).

RPE cells were dispersed enzymatically by incubating pieces of RPE-choroid for 5-10 min in normal Hepes-buffered external solution containing papain $\left(0 \cdot 2 \mathrm{mg} \mathrm{ml}^{-1}\right.$; Type III, Sigma), cysteine (3 mM) and EGTA-NaOH (3 mM), but no added $\mathrm{Ca}^{2+}$ or $\mathrm{Mg}^{2+}$. The tissue was washed with normal external solution containing $0.1 \%$ bovine serum albumin and then gently triturated by drawing it several times through the opening of a fire-polished Pasteur pipette. Repeating this procedure several times yielded numerous intact RPE cells. Viable cells could be isolated from pieces of RPE-choroid that had been stored at $4{ }^{\circ} \mathrm{C}$ for 1 or 2 days in normal Hepes external solution.

\section{Perforated patch recording}

Isolated RPE cells were transferred to a Lucite recording chamber with a glass coverslip bottom (total volume $=400-500 \mu \mathrm{l}$ ) and allowed to settle for several minutes before starting perfusion. In some experiments, the glass coverslip was coated with poly-lysine to promote cell adhesion. Solutions were delivered to one end of the chamber by gravity feed at a rate of 1-2 $\mathrm{ml} \mathrm{min}^{-1}$ and removed at the opposite end by suction. Solutions were changed using two six-way distribution valves connected to a four-way slider valve (Hodgkin, McNaughton, Nunn \& Yau, 1984). Cells were rejected for recording if they were rounded or if the cytoplasm appeared vesicularized. All experiments were conducted at room temperature $\left(20-25^{\circ} \mathrm{C}\right)$ within $4 \mathrm{~h}$ of dissociation.

Membrane currents were recorded by the perforated patch recording technique (Horn \& Marty, 1988). Pipettes were pulled from 7052 glass tubing (Garner Glass, Claremont, CA, USA) using a 
multistage programmable puller (Sutter Instruments, San Rafael, CA, USA) and coated with Sylgard (Dow Corning, Midland, MI, USA). Prior to use, pipette tips were heat-polished to a bubble test number between 6.0 and 6.5 cc using a $10 \mathrm{cc}$ syringe (Corey \& Stevens, 1983), which corresponded to a resistance of 1-5 M $\Omega$ when filled with internal solution and placed in normal external solution. Patch pipettes were front-filled with a $200-300 \mu \mathrm{m}$ column of internal solution and then backfilled with internal solution containing $120 \mathrm{mg} \mathrm{ml}^{-1}$ amphotericin $B$. Series resistance commonly decreased to less than $25 \mathrm{M} \Omega$ within 5-15 min after gigaseal formation on the basolateral membrane.

Currents were recorded with an Axopatch 1C amplifier (Axon Instruments, Foster City, CA, USA) with the built-in low-pass filter set to $1 \mathrm{kHz}$ unless noted otherwise. Recordings were referenced to a $\mathrm{Ag}-\mathrm{AgCl}$ electrode separated from the bath by a short column of $150 \mathrm{~mm} \mathrm{KCl} \mathrm{set}$ in $4 \%$ agar. Command potentials were generated by software control (pClamp, Axon Instruments). Signals were digitized on line and stored on disk in a microcomputer for subsequent analysis. Currents were evoked by stepping the membrane potential from a holding potential to various test potentials to investigate their time dependency or by ramping the membrane voltage for the construction of continuous current-voltage curves. Membrane capacitance $(C)$ was estimated by integrating the capacitative transient recorded in the absence of filtering. Series resistance $\left(R_{\mathrm{s}}\right)$ was determined by fitting the relaxation of the capacitative transient to a single exponential to find the time constant, $\tau$, and then calculating $R_{\mathrm{S}}$ from the relationship $R_{\mathrm{S}}=\tau / C$. In most experiments, $R_{\mathrm{S}}$ was uncompensated. Pipette tip potentials and liquid junction potentials at the interface between the bathing solution and the agar bridge connected to the reference electrode were measured against a flowing $\mathrm{KCl}$ bridge and were used to correct the apparent membrane potential as described previously (Hughes \& Steinberg, 1990).

The selectivity of the cAMP-activated conductance to different anions was assessed from reversal potential shifts produced by substituting $\mathrm{Cl}^{-}$in the bathing solution with test anions according to the equation

$$
P_{\mathrm{x}} / P_{\mathrm{Cl}}=\left[\mathrm{Cl}^{-}\right]_{0} /\left[\mathrm{X}^{-}\right]_{0} \exp \left(\left(V_{\mathrm{Cl}}-V_{\mathrm{x}}\right) F / R T\right) .
$$

where $V_{\mathrm{Cl}}$ and $V_{\mathrm{x}}$ are the reversal potentials of the cAMP-activated current measured in the absence and presence of the test anion, $\left[\mathrm{Cl}^{-}\right]_{0}$ is the initial extracellular $\mathrm{Cl}^{-}$concentration, $\left[\mathrm{X}^{-}\right]_{0}$ is the extracellular concentration of test anion, $P_{\mathrm{x}} / P_{\mathrm{Cl}}$ is the ratio of test anion to $\mathrm{Cl}^{-}$permeabilities and $F, R$ and $T$ have their usual meanings. Use of this equation assumes a constant intracellular composition. However, since $\mathrm{Cl}^{-}$flux through the amphotericin B-permeabilized membrane patch was rate limiting (see below), the intracellular activities of $\mathrm{Cl}^{-}$and test anions probably changed following alterations in bath composition. In support of this idea, while monitoring the cell's $I-V$ relationship during the substitution of extracellular $\mathrm{Cl}^{-}$with $\mathrm{I}^{-}, \mathrm{NO}_{3}^{-}$, or $\mathrm{Br}^{-}$, we observed time-dependent changes in the zero current potential $\left(V_{0}\right) ; V_{0}$ would first hyperpolarize as the solution composition change reached the cell membrane, and then slowly depolarize, presumably as a result of the intracellular $\mathrm{Cl}^{-}$activity decreasing and/or the intracellular activity of test anion increasing (not shown). Similar long-term effects of $\mathrm{Cl}^{-}$substitutes have been noted in pancreatic acinar cells (Evans \& Marty, 1986). To avoid the influence of these secondary changes on permeability ratio, we followed the change in the $I-V$ relationship during the substitution of extracellular $\mathrm{Cl}^{-}$with the test anion in the absence and presence of cAMP and calculated the biionic reversal potential from the difference between currents measured during the maximum hyperpolarization of $V_{0}$.

\section{RESULTS}

\section{Effects of cAMP on whole-cell currents}

The predominant current in bullfrog RPE cell is an outwardly rectifying $\mathrm{K}^{+}$ current, which activates in response to membrane depolarizations positive to about $-30 \mathrm{mV}$ and then slowly inactivates (Hughes \& Steinberg, 1990). We found that this current was inhibited by forskolin, and, to a lesser extent, cAMP (authors' unpublished observation). To examine the effect of cAMP and forskolin on timeindependent currents, we inactivated the outwardly rectifying $\mathrm{K}^{+}$current by holding the membrane potential at $-10 \mathrm{mV}$ between test potentials (Hughes \& 
$\boldsymbol{A}$

Control

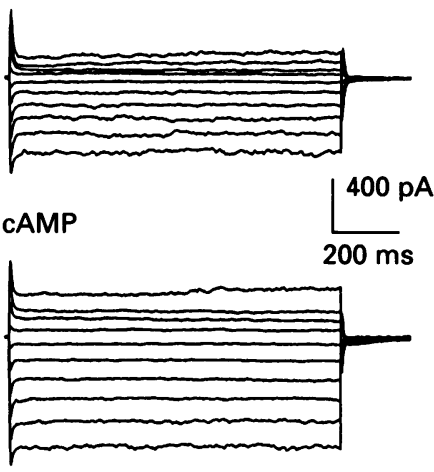

C
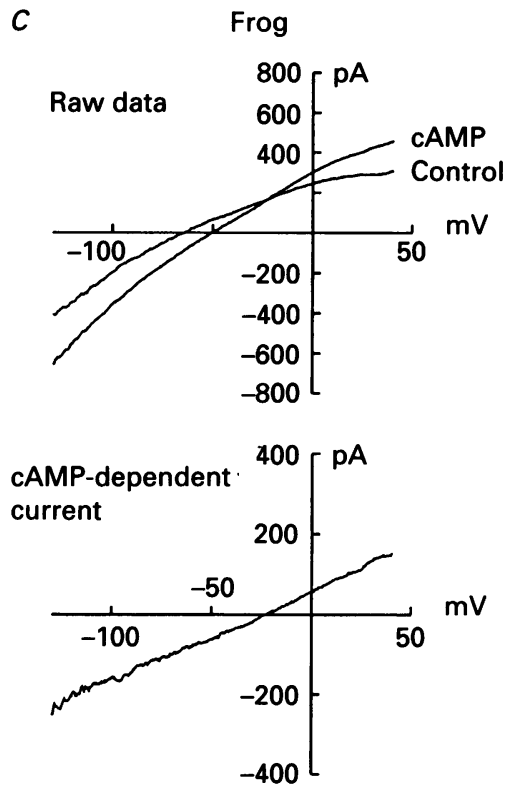

$B$

Control

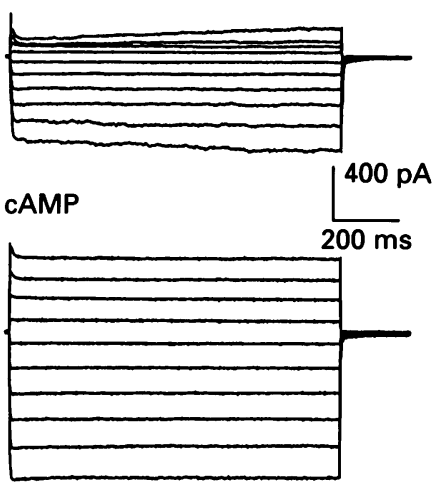

$D$
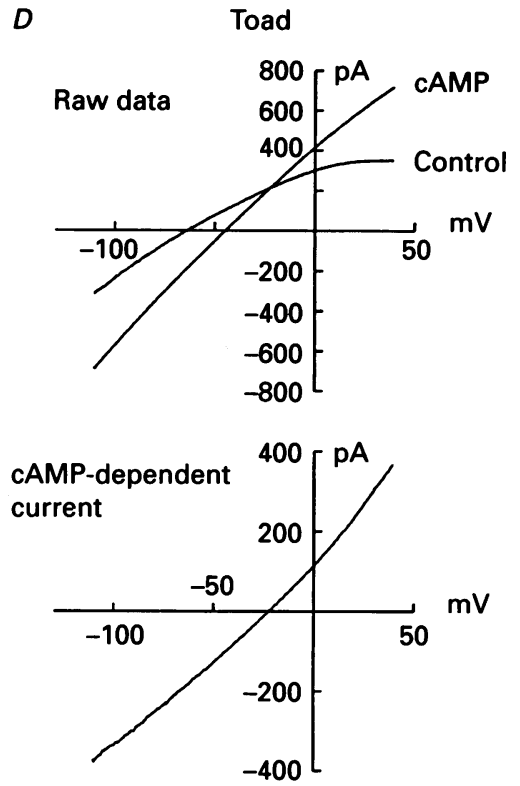

Fig. 1. Effect of cAMP on whole-cell currents in isolated RPE cells of the bullfrog ( $A$ and $C)$ and marine toad $(B$ and $D)$. Families of whole-cell currents $(A$ and $B)$ were evoked by voltage pulses from a holding potential of $-10 \mathrm{mV}$ potentials between -120 and $+60 \mathrm{mV}$ in $20 \mathrm{mV}$ steps. Upper panels show currents recorded under control conditions and lower panels show currents recorded while superfusing the cell with 1 mM cAMP plus $0 \cdot 1 \mathrm{~mm}$ IBMX. Continuous $I-V$ curves $(C$ and $D)$ were generated in the same cells by measuring the current evoked by voltage ramps between -130 and $+40 \mathrm{mV}$ from a holding potential of $-10 \mathrm{mV}$. cAMP-dependent current is the difference between currents recorded in the presence and absence of cAMP.

Steinberg, 1990). This manoeuvre was not necessary in RPE cells of the marine toad, since they rarely exhibited the delayed rectifier current.

Figure $1 A$ compares families of whole-cell currents recorded in the same bullfrog $\mathrm{RPE}$ cell bathed in normal $\mathrm{HCO}_{3}^{-}$external solution (top panel) and in normal 
$\mathrm{HCO}_{3}{ }^{-}$external solution containing $1 \mathrm{~mm}$ cAMP plus $0 \cdot 1 \mathrm{~mm}$ IBMX (3-isobutyl-1methylxanthine) (bottom panel). Prior to cAMP addition, currents were time independent and larger in response to hyperpolarizing voltage pulses than to depolarizing voltage pulses. This inward rectification is the result of a caesium- and barium-sensitive $\mathrm{K}^{+}$conductance (Hughes \& Steinberg, 1990). The bottom panel

TABLE 2. Effect of cAMP or forskolin on membrane parameters of isolated frog and toad RPE cells

\begin{tabular}{|c|c|c|c|c|}
\hline Species & Bathing solution & $\begin{array}{c}V_{0}^{i} \\
(\mathrm{mV})\end{array}$ & $\begin{array}{c}V_{0}^{t} \\
(\mathrm{mV})\end{array}$ & $\begin{array}{c}\Delta V_{0} \\
(\mathrm{mV})\end{array}$ \\
\hline Rana catesbeiana & Normal $\mathrm{HCO}_{3}^{-}$ & $\begin{array}{c}-56 \cdot 2 \pm 3 \cdot 5 \\
(19)\end{array}$ & $\begin{array}{c}-45 \cdot 6 \pm 2 \cdot 6 \\
(19)\end{array}$ & $\begin{array}{c}10 \cdot 6 \pm 1 \cdot 2 \\
(19)\end{array}$ \\
\hline Rana catesbeiana & Normal Hepes & $\begin{array}{c}-63 \cdot 3 \pm 3 \cdot 5 \\
(16)\end{array}$ & $\begin{array}{c}-51 \cdot 2 \pm 2 \cdot 7 \\
(16)\end{array}$ & $\begin{array}{c}12 \cdot 1 \pm 2 \cdot 1 \\
(16)\end{array}$ \\
\hline Bufo marinus & Normal Hepes & $\begin{array}{c}-59 \cdot 2 \pm 3 \cdot 5 \\
(16)\end{array}$ & $\begin{array}{c}-38 \cdot 2 \pm 2 \cdot 7 \\
(16)\end{array}$ & $\begin{array}{c}21 \cdot 1 \pm 2 \cdot 1 \\
\quad(16)\end{array}$ \\
\hline Species & Bathing solution & $\begin{array}{l}g_{\mathrm{m}}^{\mathrm{i}} \\
(\mathrm{nS})\end{array}$ & $\begin{array}{l}g_{\mathrm{m}}{ }^{\prime} \\
(\mathrm{nS})\end{array}$ & $\begin{array}{l}\Delta g_{\mathrm{m}} \\
(\mathrm{nS})\end{array}$ \\
\hline Rana catesbeiana & 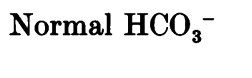 & $\begin{array}{c}3 \cdot 43 \pm 0 \cdot 47 \\
(19)\end{array}$ & $\begin{array}{c}5 \cdot 03 \pm 0 \cdot 62 \\
(19)\end{array}$ & $\begin{array}{c}1 \cdot 60 \pm 0 \cdot 19 \\
(19)\end{array}$ \\
\hline Rana catesbeiana & Normal Hepes & $\begin{array}{c}3.33 \pm 0.31 \\
(16)\end{array}$ & $\begin{array}{c}4.93 \pm 0.43 \\
(16)\end{array}$ & $\begin{array}{c}1 \cdot 60 \pm 0 \cdot 23 \\
(16)\end{array}$ \\
\hline Bufo marinus & Normal Hepes & $\begin{array}{c}3 \cdot 64 \pm 0 \cdot 31 \\
(16)\end{array}$ & $\begin{array}{c}7 \cdot 35 \pm 0 \cdot 43 \\
(16)\end{array}$ & $\begin{array}{c}3 \cdot 71 \pm 0 \cdot 23 \\
(16)\end{array}$ \\
\hline
\end{tabular}

Resting membrane voltage $\left(V_{0}\right)$ and slope conductance in the voltage range -80 to $-60 \mathrm{mV}$ $\left(g_{\mathrm{m}}\right)$. Superscripts $\mathrm{i}$ and f represent initial and final values. Means \pm s.E.M. Numbers in parentheses represent number of observations.

shows that in the presence of cAMP and IBMX, currents remained time independent, but their amplitude was significantly larger, indicating an increase in membrane conductance.

Figure $1 C$ shows the effect of cAMP on the current-voltage $(I-V)$ relationship of the same cell as that shown in Fig. $1 A$. The upper panel compares $I-V$ curves obtained in the absence and presence of cAMP by measuring currents evoked by a voltage ramp between +40 and $-130 \mathrm{mV}$ from a holding potential of $-10 \mathrm{mV}$. cAMP had two main effects: it increased the slope conductance in the physiological voltage range $(-80$ to $-60 \mathrm{mV}$ ) from 4.90 to $6.85 \mathrm{nS}$ and it shifted the zero current potential $\left(V_{0}\right)$ from $-64 \cdot 7$ to $-50 \cdot 6 \mathrm{mV}$. The difference between these two curves, representing the cAMP-dependent component of the whole-cell current (bottom panel), had a more or less linear $I-V$ relationship and a reversal potential of $-22.5 \mathrm{mV}$. Similar results were obtained with $20 \mu \mathrm{M}$ forskolin plus $0.1 \mathrm{~mm}$ IBMX. Figures $1 B$ and $D$ show that cAMP and IBMX had a similar effect in an isolated RPE cell of the marine toad. In general, however, the magnitude of the cAMP-activated current was larger in toad than in bullfrog cells.

Table 2 summarizes the results of similar experiments in fifty-one bullfrog and toad RPE cells stimulated with either $20 \mu \mathrm{M}$ forskolin plus $0.1 \mathrm{~mm}$ IBMX or $1 \mathrm{~mm}$ cAMP plus $0 \cdot 1 \mathrm{~mm}$ IBMX. In bullfrog cells bathed with normal $\mathrm{HCO}_{3}{ }^{-}$external solution, elevation of intracellular cAMP depolarized the $V_{0}$ by an average of $10 \cdot 6 \pm 1 \cdot 2 \mathrm{mV}$ and increased the membrane slope conductance $\left(g_{\mathrm{m}}\right)$ in the physio- 
logical voltage range by nearly $50 \%$ (row 1 ). The reversal potentials $\left(V_{\text {rev }}\right)$ of the cAMP- and forskolin-dependent currents were indistinguishable from one another and averaged $-23 \cdot 4 \pm 2 \cdot 4 \mathrm{mV}$ (range, -10 to $-49 \cdot 2 \mathrm{mV}$ ). There were no significant differences in the responses of bullfrog cells recorded in Hepes- and $\mathrm{HCO}_{3}{ }^{-}$-buffered external solutions (rows 1 and 2).

Table 2 also shows that although the resting membrane voltage and conductance of toad RPE cells were similar to those of bullfrog, the cAMP- and forskolin-induced changes in membrane parameters were considerably larger. The average reversal potential of the cAMP-activated current was somewhat less negative in toad, but this difference was not statistically significant.

Previous studies in isolated RPE-choroid preparations have shown that cAMP and forskolin produce qualitatively similar effects on fluid and ion transport and electrophysiology (Hughes et al. 1984, 1987), indicating that exogenous cAMP is somehow transported into the cell where it exerts its effects. A recent study of cAMPinduced pigment aggregation in the RPE of a teleost fish suggests that cAMP is transported into the cell by a probenecid-sensitive organic anion transporter (Burnside \& Garcia, 1992). Along these lines, we have found in the toad RPE that $1 \mathrm{~mm}$ probenecid blocked the activation of the current by exogenous cAMP but that it had no effect on the forskolin-activated current (authors' unpublished observations).

\section{Ionic dependence of cAMP-dependent current}

The average reversal potential of the cAMP-dependent current was near the $\mathrm{Cl}^{-}$ equilibrium potential $\left(E_{\mathrm{Cl}}=-27 \mathrm{mV}\right.$ for normal $\mathrm{HCO}_{3}^{-}$external solution and $-34 \mathrm{mV}$ normal Hepes external solution), suggesting that the current might be mediated by a $\mathrm{Cl}^{-}$-selective conductance. Alternatively, cAMP could activate a nonselective cation conductance whose reversal potential lies between the equilibrium potentials for $\mathrm{Na}^{+}$and $\mathrm{K}^{+}$. The large variance in the reversal potential of the cAMPactivated current (Table 2) suggested the possibility that more than one type of conductance was activated by cAMP. To distinguish between these possibilities, we examined the effect of ion substitution and specific channel blockers on the cAMPdependent conductance.

\section{Sodium}

Figure 2 shows $I-V$ plots of the cAMP-dependent current in a bullfrog cell bathed with normal $\mathrm{HCO}_{3}{ }^{-}$external solution $(A)$ and then in $0 \mathrm{Na}^{+}-\mathrm{HCO}_{3}{ }^{-}$external solution $(B)$. Under control conditions, cAMP increased the slope conductance in the voltage range -80 to $-60 \mathrm{mV}$ from 1.66 to $2 \cdot 60 \mathrm{nS}$ and shifted $V_{0}$ from $-55 \cdot 0$ to $-44 \cdot 3 \mathrm{mV}$ (upper panel, Fig. $2 A$ ). The reversal potential of the cAMP-activated current was $-25 \cdot 2 \mathrm{mV}$ (lower panel). Superfusing the cell with $0 \mathrm{Na}^{+}$external solution shifted $V_{0}$ to $-61.3 \mathrm{mV}$ and decreased the slope conductance in the voltage range -80 to $-60 \mathrm{mV}$ to $0.83 \mathrm{nS}$, suggesting the presence of a $\mathrm{Na}^{+}$conductance in the resting membrane (Fig. $2 B$ ). However, in the absence of external (and internal) $\mathrm{Na}^{+}$, cAMP evoked a response that was similar to that obtained under control conditions: the cAMP-activated current had a slope conductance of 1.29 nS, and a reversal potential of $-23.5 \mathrm{mV}$. The cAMP-induced change in $V_{0}$ was considerably larger in the absence 
$\boldsymbol{A}$
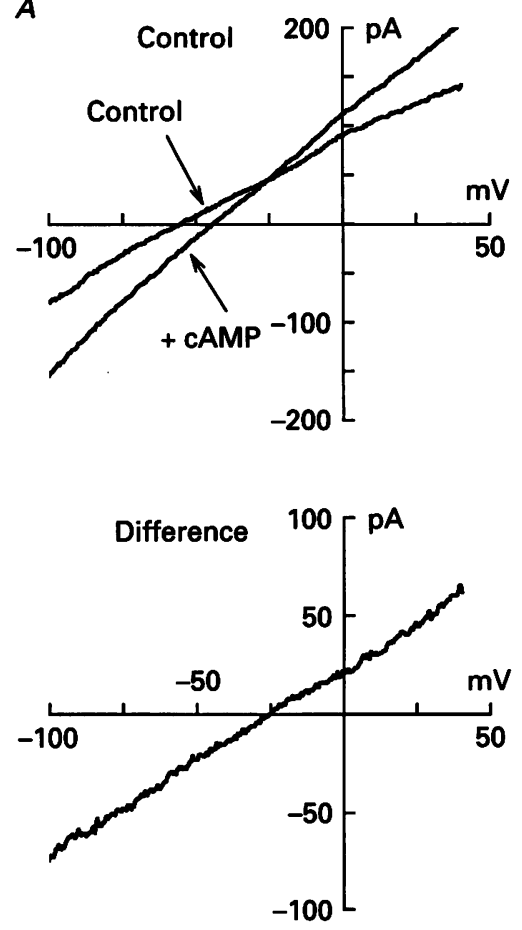

B
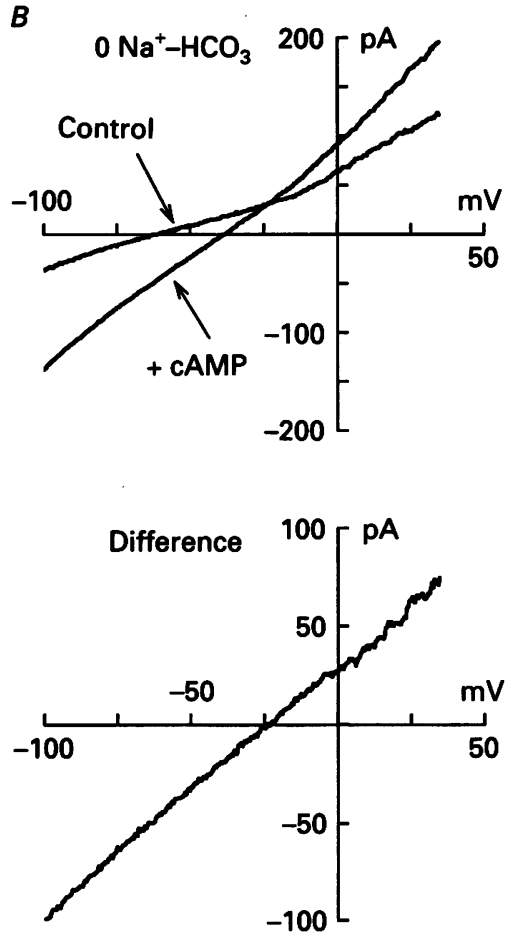

Fig. 2. Effect of $0 \mathrm{Na}^{+}$on the cAMP-activated current. $I-V$ relationships generated as described in legend for Fig. 1 . In the resting cell, $\mathrm{Na}^{+}$removal hyperpolarized the zerocurrent potential and decreased the slope conductance, but it had no effect on the reversal potential of the cAMP-dependent current ( $A$ and $B$, lower panels).

TABLE 3. Effect of $0 \mathrm{Na}^{+}$on cAMP or forskolin response

\begin{tabular}{|c|c|c|c|c|}
\hline Bathing solution & $\begin{array}{c}V_{m}^{1} \\
(m V)\end{array}$ & $\begin{array}{c}V_{\mathrm{m}}^{\mathrm{l}} \\
(\mathrm{mV})\end{array}$ & $\begin{array}{l}\Delta V_{m} \\
(m V)\end{array}$ & $\begin{array}{c}V_{\mathrm{rev}} \\
(\mathrm{mV})\end{array}$ \\
\hline Control & $\begin{array}{c}-51 \cdot 7 \pm 6 \cdot 8 \\
(9)\end{array}$ & $\begin{array}{c}-37 \cdot 5 \pm 3.5 \\
(9)\end{array}$ & $\underset{(9)}{14 \cdot 2 \pm 4 \cdot 8}$ & $\begin{array}{c}-22 \cdot 4 \pm 2 \cdot 6 \\
(9)\end{array}$ \\
\hline $0 \mathrm{Na}^{+}$ & $\begin{array}{c}-56 \cdot 3 \pm 4 \cdot 7 \\
(9)\end{array}$ & $\begin{array}{c}-41 \cdot 2 \pm 3 \cdot 7 \\
(9)\end{array}$ & $\underset{(9)}{15 \cdot 1 \pm 3 \cdot 7}$ & $\begin{array}{c}-24 \cdot 9 \pm 2 \cdot 1 \\
(9)\end{array}$ \\
\hline Bathing solution & $\begin{array}{c}g_{\mathrm{m}}{ }^{1} \\
(\mathrm{nS})\end{array}$ & $\begin{array}{c}g_{\mathrm{m}}{ }^{\mathrm{P}} \\
(\mathrm{nS})\end{array}$ & $\begin{array}{l}\Delta g_{\mathrm{m}} \\
(\mathrm{nS})\end{array}$ & \\
\hline Control & $\begin{array}{c}3.36 \pm 0.49 \\
(9)\end{array}$ & $\underset{(9)}{5 \cdot 67 \pm 0.88}$ & $\underset{(9)}{2.31 \pm 0.48}$ & \\
\hline $0 \mathrm{Na}^{+}$ & $\begin{array}{c}1.99 \pm 0.39 \\
(9)\end{array}$ & $\underset{(9)}{3.93 \pm 0.72}$ & $\begin{array}{c}1.93 \pm 0.49 \\
(9)\end{array}$ & \\
\hline
\end{tabular}

Measurements in three frog cells and six toad cells. Abbreviations as in Table 2.

of $\mathrm{Na}^{+}$than it was in its presence $(23 \cdot 4 \mathrm{vs} .10 \cdot 7 \mathrm{mV}$ for control) as would be expected if the main effect of cAMP were to increase the membrane conductance to an ion other than $\mathrm{Na}^{+}$.

Table 3 summarizes the results of experiments testing the effect of cAMP or forskolin in three bullfrog cells and six toad cells bathed in normal and $\mathbf{0 ~} \mathrm{Na}^{+}$ 
external solutions. Results obtained in $\mathrm{HCO}_{3}{ }^{-}$- and Hepes-buffered external solutions were indistinguishable from one another and are pooled together. The reversal potential and slope conductance of the cAMP-activated current were nearly the same in the presence and absence of external $\mathrm{Na}^{+}$, indicating that the current is not mediated by either a $\mathrm{Na}^{+}$or non-selective channel or an electrogenic $\mathrm{Na}^{+}$-coupled transporter. In separate experiments, the cAMP-induced current was unaffected by $0 \cdot 1 \mathrm{~mm}$ ouabain in the external solution, indicating that the current does not reflect an increase in $\mathrm{Na}^{+}-\mathrm{K}^{+}$pump current.

\section{Potassium}

To test the possibility that cAMP modulates the inwardly rectifying $\mathrm{K}^{+}$ conductance (Hughes \& Steinberg, 1990), the cAMP response was measured after replacing extracellular $\mathrm{Na}^{+}$with $\mathrm{K}^{+}$or blocking the $\mathrm{K}^{+}$channels with $\mathrm{Ba}^{2+}$. The reversal potential of the cAMP-activated current was unaltered by either treatment. In one series of experiments on three cells, the $V_{\text {rev }}$ averaged $-31 \cdot 0 \pm 1 \cdot 2 \mathrm{mV}( \pm$ S.D. $)$ with $112 \mathrm{~mm} \mathrm{~K}^{+}$in the bath compared to an average value of $-31.5 \pm 1.5 \mathrm{mV}$ measured in the same cells under control conditions. In three other cells, $V_{\text {rev }}$ averaged $-30 \cdot 4 \pm 2 \cdot 2 \mathrm{mV}$ in the presence of $5 \mathrm{~mm}$ external $\mathrm{Ba}^{2+}$ and $-29 \cdot 8 \pm 0.7 \mathrm{mV}$ under control conditions. These results indicate that cAMP does not modulate the inwardly rectifying $\mathrm{K}^{+}$channel.

\section{Chloride}

The experiments described above strongly argue against the idea that $\mathrm{K}^{+}, \mathrm{Na}^{+}$or $\mathrm{HCO}_{3}{ }^{-}$-selective channels mediate the cAMP-activated current and, by exclusion, suggest the involvement of $\mathrm{Cl}^{-}$channels. The reversal potential of the cAMPactivated current, however, averaged 4 to $14 \mathrm{mV}$ more positive than the $\mathrm{Cl}^{-}$ equilibrium potential $\left(E_{\mathrm{Cl}}\right)$ calculated by the Nernst equation from the $\mathrm{Cl}^{-}$ concentrations of the internal (pipette filling) and external solutions (Table 2). These calculated values, however, may not accurately reflect $E_{\mathrm{Cl}}$ across the cell membrane because the one-sided amphotericin $B$ channels in the membrane patch beneath the pipette have a relatively low $\mathrm{Cl}^{-}$permeability and do not allow the rapid equilibration of $\mathrm{Cl}^{-}$between the pipette and cell interior (Rae \& Cooper, 1990). Under these conditions, intracellular $\mathrm{Cl}^{-}$activity can be affected by $\mathrm{Cl}^{-}$fluxes across the cell membrane through conductances, exchangers or co-transporters. To minimize conductive $\mathrm{Cl}^{-}$fluxes across the membrane, we held the membrane potential $\left(V_{\mathrm{m}}\right)$ at the value of $E_{\mathrm{Cl}}$ defined by the Nernst equation for the $\mathrm{Cl}^{-}$concentrations in the pipette and bathing solutions. When toad RPE cells were bathed in normal Hepes external solution and $V_{\mathrm{m}}$ was held at the expected $E_{\mathrm{Cl}}$ of $-34 \mathrm{mV}$, the cAMPactivated current reversed at $-36 \cdot 1 \pm 3.8 \mathrm{mV}$ (mean \pm s.D., $n=20$ ). The close agreement between $V_{\mathrm{rev}}$ and $E_{\mathrm{cl}}$ provides strong evidence that the conductance is $\mathrm{Cl}^{-}$ selective.

To further test the idea of $\mathrm{Cl}^{-}$selectivity, we measured the reversal potential of the cAMP-activated current as a function of different extracellular $\mathrm{Cl}^{-}$concentrations. Figure 3 shows the results of a representative experiment in which the $I-V$ relationship of a toad RPE cell was determined at various external $\mathrm{Cl}^{-}$concentrations in the absence and presence of cAMP. Under control conditions $(A), V_{0}$ shifted in the 
positive direction with decreasing concentrations of extracellular $\mathrm{Cl}^{-}$, indicating that this particular cell had a finite $\mathrm{Cl}^{-}$conductance at rest. In the presence of $1 \mathrm{mM}$ cAMP and $0 \cdot 1 \mathrm{mM}$ IBMX $(B)$, the slope conductance was larger at all $\mathrm{Cl}^{-}$ concentrations, and decreasing the external $\mathrm{Cl}^{-}$concentration produced a much

$\boldsymbol{A}$
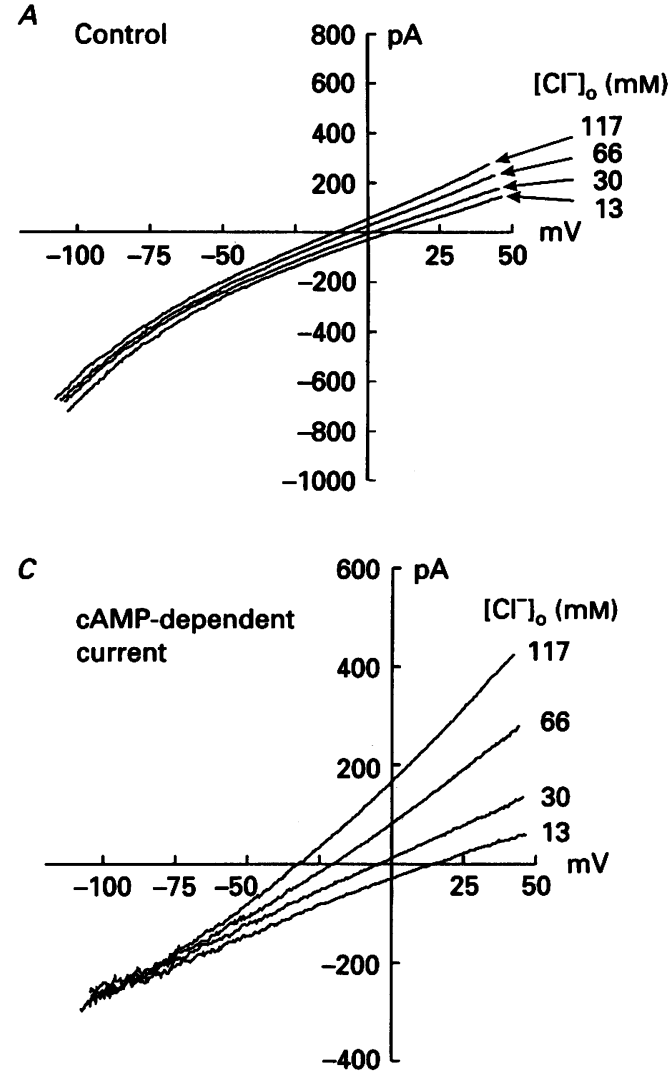

$B$

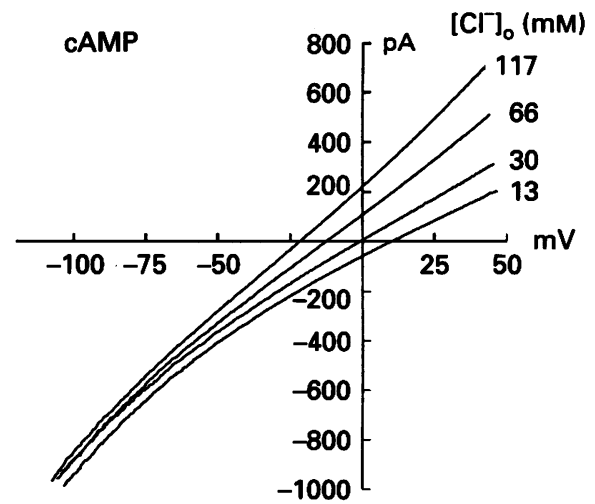

$D$

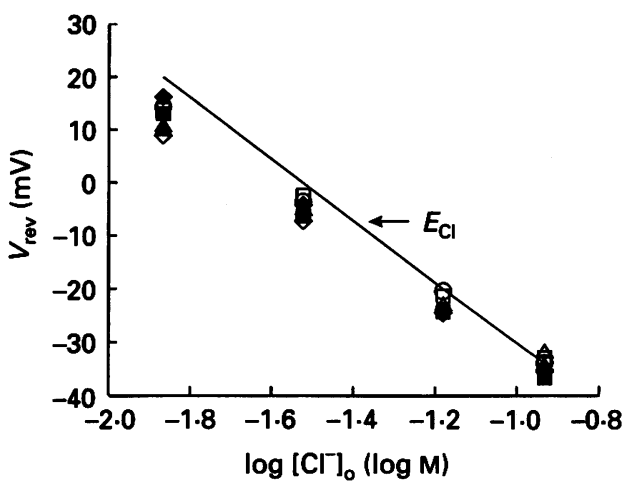

Fig. 3. Dependence of the cAMP-activated current on extracellular $\mathrm{Cl}^{-}$concentration $(\mathrm{mM}) .(A)$ and $(B)$ show the $I-V$ relationships for a single toad RPE cell measured at 4 different concentrations of extracellular $\mathrm{Cl}^{-}$(methanesulphonate substitution) under resting conditions and in the presence of $1 \mathrm{mM}$ cAMP and $0.1 \mathrm{mM}$ IBMX, respectively. The extracellular solution was $\mathrm{Na}^{+}$-free $\left(\mathrm{K}^{+}\right.$substitution) to block $\mathrm{Na}$-dependent $\mathrm{Cl}^{-}$ transport. The difference between these two records gives the $I-V$ relationship of the cAMP-dependent current $(C)$. Note the positive shift in the reversal potential of the cAMP-dependent current with decreasing extracellular $\mathrm{Cl}^{-}$concentrations. $D$, relationship between the reversal potential of the cAMP-dependent current $\left(V_{\text {rev }}\right)$ and the logarithm of the extracellular $\mathrm{Cl}^{-}$concentration $\left(\log \left[\mathrm{Cl}^{-}\right]_{0}\right)$. Data from 7 cells. The straight line represents the theoretical relationship for a perfectly selective $\mathrm{Cl}^{-}$channel predicted by the Nernst equation.

larger positive shift in $V_{0}$. Figure $3 C$ plots the $I-V$ relationships of the difference currents and shows the dependence of the cAMP-activated current on external $\mathrm{Cl}^{-}$ concentration $\left(\left[\mathrm{Cl}^{-}\right]_{\mathrm{o}}\right)$. Decreasing $\left[\mathrm{Cl}^{-}\right]_{\mathrm{o}}$ produced a positive shift in the reversal potential of the cAMP-activated current and also affected the shape of the $I-V$ 
relationship : the $I-V$ relationship was outwardly rectifying at $\left.117 \mathrm{~mm}^{\left[\mathrm{Cl}^{-}\right.}\right]_{0}$ but was more or less linear at a $\mathrm{Cl}^{-}$concentration of $30 \mathrm{~mm}$, when the $\mathrm{Cl}^{-}$concentration gradient across the membrane was eliminated. Figure $3 D$ plots the reversal potential of the cAMP-activated current $\left(V_{\text {rev }}\right)$ as a function of the logarithm of the

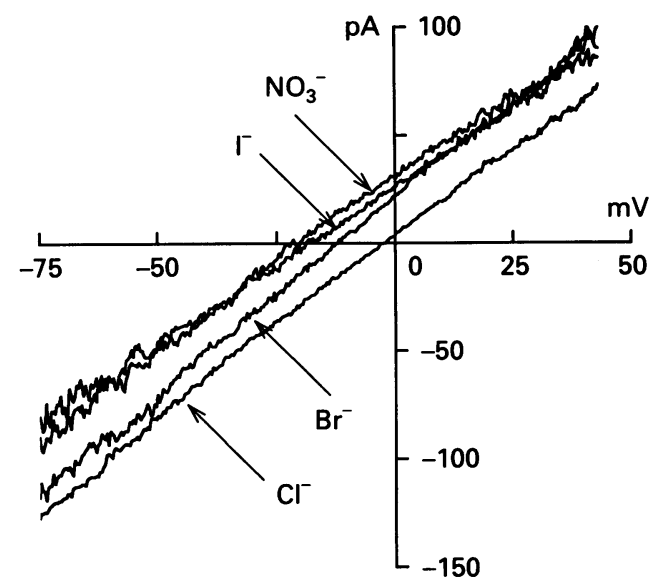

Fig. 4. Anion selectivity of the cAMP-activated current. $I-V$ curves for the cAMPactivated current with $30 \mathrm{mM} \mathrm{Cl}^{-}$or $30 \mathrm{mM} \mathrm{Br}^{-}, \mathrm{I}^{-}$, or $\mathrm{NO}_{3}^{-}$in the external solution (balance methanesulphonate). Each trace represents the difference between $I-V$ curves recorded in the presence and absence of cAMP. Holding potential was $-10 \mathrm{mV}$. Following the substitution of $\mathrm{Cl}^{-}$with a test anion, the zero current potential hyperpolarized within $10-20 \mathrm{~s}$ as the solution change occurred outside the cell membrane and then depolarized, probably as a result of an intracellular depletion of $\mathrm{Cl}^{-}$and accumulation of substitute anion. The difference currents were derived from the $I-V$ curves obtained during the peak hyperpolarization.

extracellular $\mathrm{Cl}^{-}$concentration $\left(\log \left[\mathrm{Cl}^{-}\right]_{0}\right)$ for seven cells (each represented by a different symbol). The straight line represents the theoretical relationship for a perfectly selective $\mathrm{Cl}^{-}$channel predicted by the Nernst equation. The close agreement between $V_{\mathrm{rev}}$ and $E_{\mathrm{Cl}}$ over a wide range of external $\mathrm{Cl}^{-}$concentrations provides strong evidence that cAMP activates a $\mathrm{Cl}^{-}$-selective conductance. The deviation of the data from the ideal relation at the lower $\mathrm{Cl}^{-}$concentrations suggests a small but finite permeability of the conductance to methanesulphonate. The permeability ratio $\left(P_{\mathrm{MeSO}_{3}} / P_{\mathrm{Cl}}\right)$ calculated by eqn (1) from the shift in $V_{\mathrm{rev}}$ produced by changing $\left[\mathrm{Cl}^{-}\right]_{0}$ from 117 to $13 \mathrm{~mm}$ is $0.05(n=7)$.

\section{Anion selectivity}

To characterize the anion selectivity of the cAMP-activated conductance, we measured the change in its reversal potential after replacing extracellular $\mathrm{Cl}^{-}$with foreign anions. Figure 4 shows the results of a representative experiment in which the $I-V$ relationship of the cAMP-activated current was determined in a toad RPE cell bathed with $30 \mathrm{~mm} \mathrm{Cl}{ }^{-}$or with $30 \mathrm{~mm} \mathrm{I} \mathrm{I}^{-}, \mathrm{Br}^{-}$or $\mathrm{NO}_{3}^{-}$. The reversal potential was $-3 \mathrm{mV}$ in the presence of $\mathrm{Cl}^{-}$and it shifted to $-12,-15$ and $-20 \mathrm{mV}$ in the presence of $\mathrm{Br}^{-}, \mathrm{I}^{-}$, and $\mathrm{NO}_{3}^{-}$, respectively. These negative shifts in reversal 

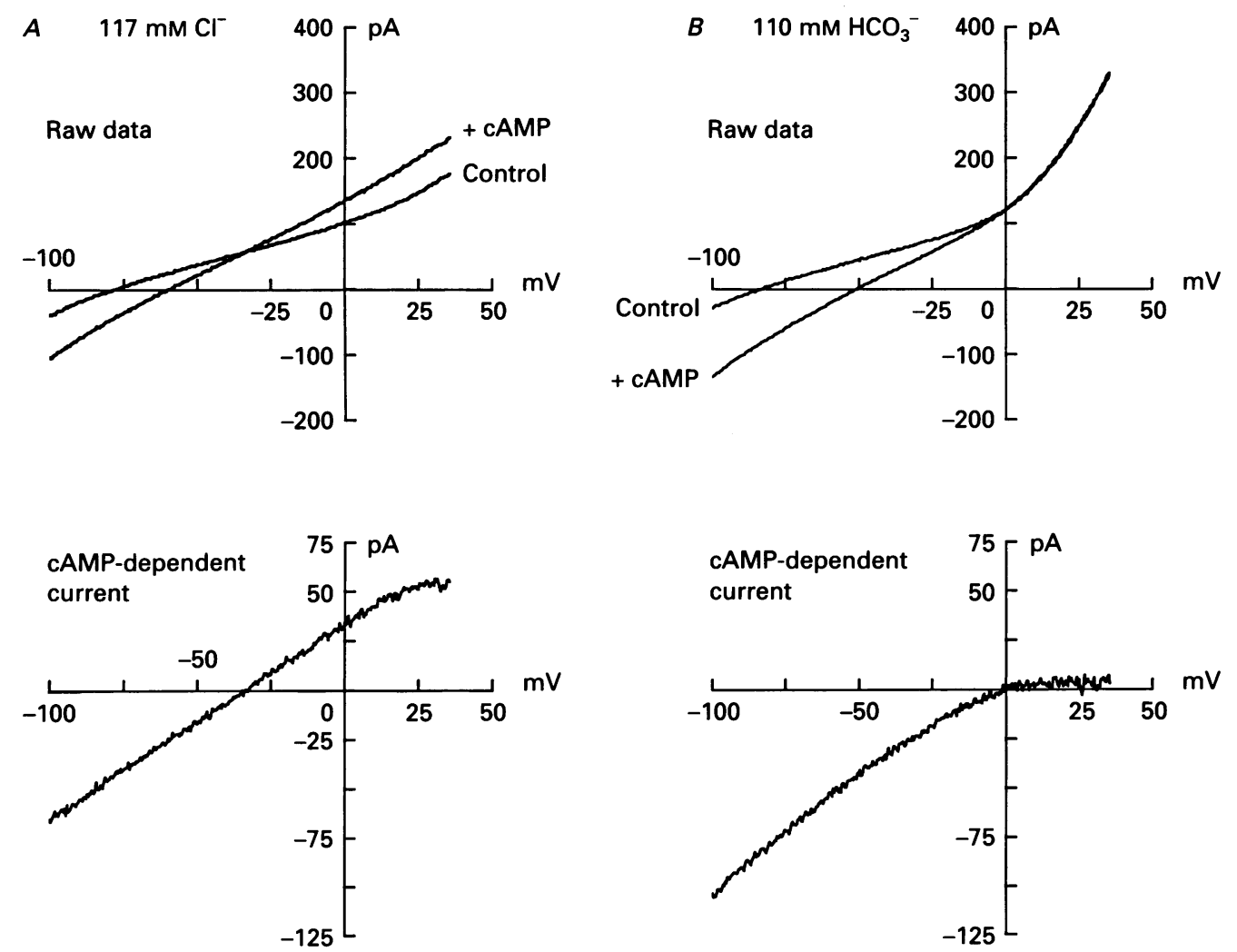

Fig. 5. The effect of high $\mathrm{HCO}_{3}{ }^{-}$on the cAMP-activated current. $I-V$ curves from a toad RPE cell bathed in $0 \mathrm{Na}^{+}-$Hepes external solution equilibrated with air $(A)$ or $0 \mathrm{Na}^{+}$-high $\mathrm{HCO}_{3}{ }^{-}$external solution $(B)$ equilibrated with $13 \% \mathrm{CO}_{2}(\mathrm{pH} 7 \cdot 6)$. Pipette contained Hepes-buffered internal solution.

TABLE 4. Relative anion permeability and conductance of the cAMP-activated conductance

$\begin{array}{lcc}\text { Anion } & P_{\mathrm{X}} / P_{\mathrm{Cl}} & g_{\mathrm{x}} / g_{\mathrm{Cl}} \\ \mathrm{Br}^{-} & 1 \cdot 31 \pm 0 \cdot 11(3) & 1 \cdot 20 \pm 0 \cdot 13(3) \\ \mathrm{I}^{-} & 1 \cdot 67 \pm 0 \cdot 15(3) & 1 \cdot 09 \pm 0 \cdot 14(3) \\ \mathrm{NO}_{3}{ }^{-} & 1 \cdot 75 \pm 0.33(3) & 1 \cdot 65 \pm 0 \cdot 34(3)\end{array}$

Data are means \pm S.E.M. of measurements obtained with $30 \mathrm{~mm} \mathrm{Cl}-, \mathrm{Br}^{-}, \mathrm{I}^{-}$or $\mathrm{NO}_{3}^{-}$. Permeability ratios $P_{\mathrm{X}} / P_{\mathrm{Cl}}$, where $\mathrm{X}$ is $\mathrm{Br}^{-}, \mathrm{I}^{-}$or $\mathrm{NO}_{3}^{-}$, were calculated using eqn (1). Conductance ratios $g_{\mathrm{X}} / g_{\mathrm{Cl}}$ are the ratios of chord conductances in $\mathrm{Br}^{-}, \mathrm{I}^{-}$, or $\mathrm{NO}_{3}{ }^{-}$to that in $\mathrm{Cl}^{-}$. Chord conductance was measured as the slope between the reversal potential and the reversal potential plus $25 \mathrm{mV}$.

potential indicate that the cAMP-activated conductance has a higher permeability to $\mathrm{Br}^{-}, \mathrm{I}^{-}$and $\mathrm{NO}_{3}^{-}$than to $\mathrm{Cl}^{-}$. Table 4 summarizes the average anion permeability and conductance ratios calculated from similar measurements in three cells. The permeability sequence was $\mathrm{NO}_{3}^{-}=\mathrm{I}^{-}>\mathrm{Br}^{-}>\mathrm{Cl}^{-}$and the conductance sequence was $\mathrm{NO}_{3}^{-}>\mathrm{Br}^{-}>\mathrm{I}^{-}>\mathrm{Cl}^{-}$.

Figure $5 A$ and $B$ shows the effect of replacing external $\mathrm{Cl}^{-}$with $\mathrm{HCO}_{3}{ }^{-}$on the cAMP-activated current in a toad RPE cell. In this experiment, $\mathrm{Na}^{+}$-free solutions 
were used to eliminate currents associated with the electrogenic $\mathrm{NaHCO}_{3}$ cotransporter present in the apical membrane of the RPE (Hughes, Adorante, Miller $\&$ Lin, 1989). Figure $5 A$ shows that when the cell was bathed with $0 \mathrm{Na}^{+}-$Hepes external solution, the $I-V$ relationship of the cAMP-activated current was essentially
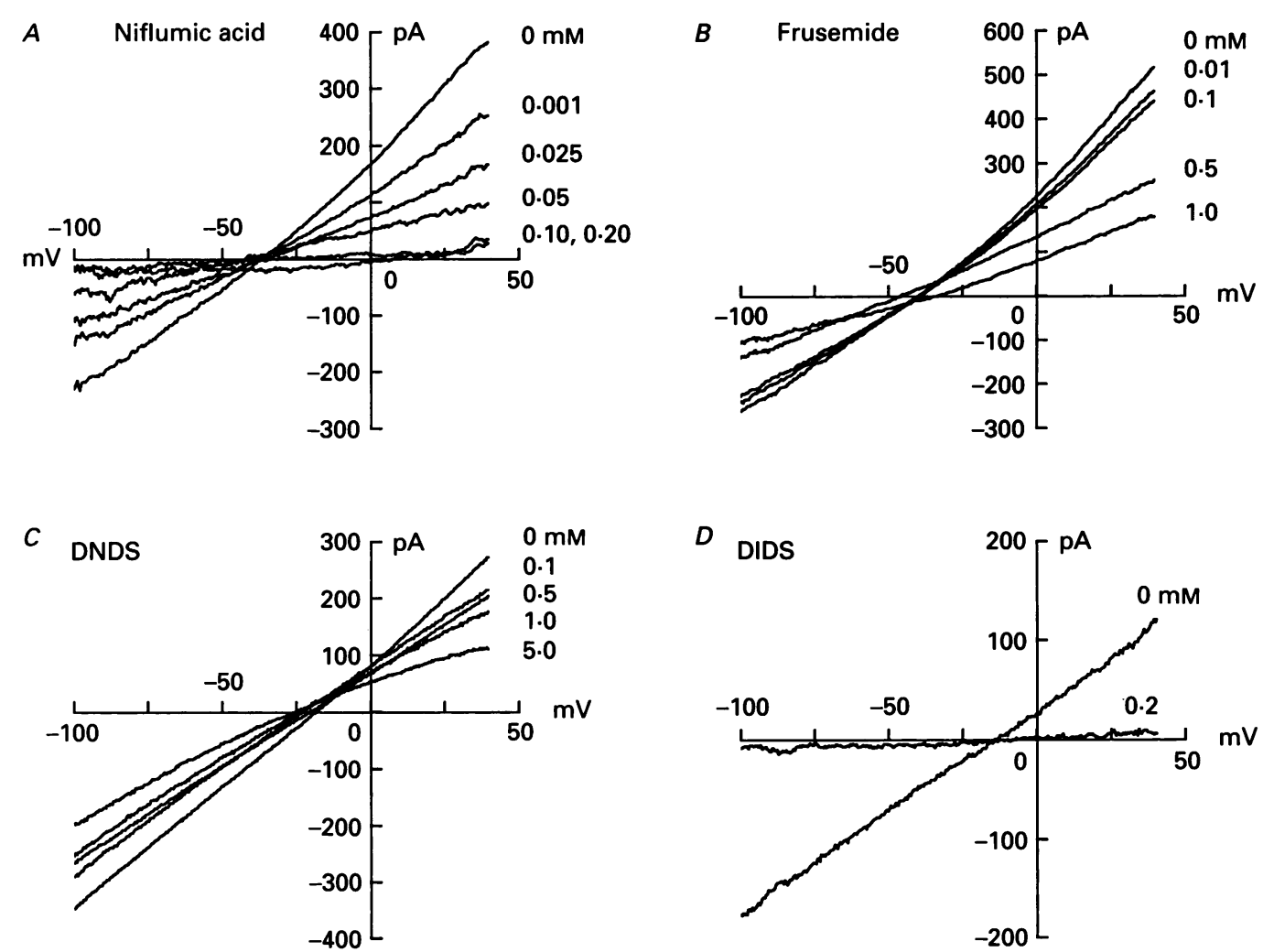

Fig. 6. Effect of $\mathrm{Cl}^{-}$transport inhibitors on the cAMP-activated current. Currents were recorded while superfusing the cell with increasing concentrations of inhibitor first in the absence and then in the presence of cAMP (1 mM) and IBMX $(0 \cdot 1 \mathrm{mM})$. All records were obtained in toad RPE cells. Numbers to the right of each trace represent the concentration of inhibitor (mM). Abbreviations: DNDS, 4,4'-dinitro-2, $2^{\prime}$-stilbene disulphonic acid, DIDS, 4,4'-diisothiocyanatostilbene-2, $2^{\prime}$-disulphonic acid.

linear and it reversed at $-30 \mathrm{mV}$. When the same cell was superfused with $0 \mathrm{Na}^{+}$-high $\mathrm{HCO}_{3}{ }^{-}$external solution, the reversal potential shifted to $0 \mathrm{mV}$ (Fig. $5 B$ ). In addition, outward current was negligible, indicating little inward movement of $\mathrm{HCO}_{3}^{-}$through the conductance. In another cell, outward currents were again smaller in high $\mathrm{HCO}_{3}^{-}$than in high $\mathrm{Cl}^{-}$solutions, and the reversal potential shifted from -26 to $-9 \mathrm{mV}$. These effects of high $\mathrm{HCO}_{3}{ }^{-}$were completely reversible. The permeability ratios, $P_{\mathrm{HCO}_{3}} / P_{\mathrm{Cl}}$, for these two cells are 0.30 and 0.50 , respectively. These values probably represent an upper bound, however, since the intracellular $\mathrm{Cl}^{-}$ concentration was probably lower and the $\mathrm{HCO}_{3}{ }^{-}$concentration higher when the cell was superfused with high $\mathrm{HCO}_{3}{ }^{-}$external solution. 


\section{Blocker sensitivity}

Channel sensitivity to inhibitors is widely used as a means of discriminating between different channel types. Figure 6 shows the effect of several $\mathrm{Cl}^{-}$channel blockers on the $I-V$ relationship of the cAMP-activated current. Niflumic acid, a potent blocker of the $\mathrm{Cl}^{-}$conductance of vascular smooth muscle cells (Pacaud, Loirand, Lavie, Mironneau \& Mironneau, 1989), blocked nearly $50 \%$ of the cAMPactivated conductance at a concentration of $25 \mu \mathrm{M}$, and at a concentration of $200 \mu \mathrm{M}$ the block was nearly complete. Extracellular frusemide (Fig. $6 B$ ) and the disulphonic stilbenes DNDS $(C)$ and DIDS $(D)$ were also effective in blocking the cAMP-activated current, but only at higher concentrations. The cAMP-activated current measured at $+40 \mathrm{mV}$ was inhibited $50 \pm 6 \%$ by $1 \mathrm{~mm}$ DNDS $(n=3), 68 \pm 9 \%$ by $200 \mu \mathrm{M}$ DIDS $(n=5)$, and $79 \pm 5 \%$ by $1 \mathrm{~mm}$ frusemide $(n=6)$.

\section{DISCUSSION}

The present study demonstrates that cAMP causes a substantial increase in membrane conductance of isolated RPE cells of the bullfrog and marine toad. The currents mediated by this cAMP-activated conductance were time independent and had an $I-V$ relationship that was essentially linear when intracellular and extracellular $\mathrm{Cl}^{-}$concentrations were equal. Several findings indicated that the conductance mediating this current is $\mathrm{Cl}^{-}$selective. First, its reversal potential was independent of changes in extracellular $\mathrm{Na}^{+}$concentration, but it was near the $\mathrm{Cl}^{-}$ equilibrium potential over a wide range of extracellular $\mathrm{Cl}^{-}$concentrations. Second, it was unaffected by either changes in extracellular $\mathrm{K}^{+}$concentration or the application of $\mathrm{K}^{+}$channel blockers. Finally, it was inhibited by a number of different $\mathrm{Cl}^{-}$channel blockers including frusemide, niflumic acid, and the disulphonic stilbene derivatives DIDS and DNDS.

\section{Membrane origin of the cAMP-activated $\mathrm{Cl}^{-}$conductance}

Like other epithelia, the RPE has two membrane domains with distinct properties. Although these whole-cell measurements do not allow us to specify the membrane location of the cAMP-activated conductance, comparisons between the present results and those obtained previously in the RPE-choroid preparation suggest that it originates in the basolateral membrane. Previous studies on the isolated RPE-choroid of the bullfrog showed that cAMP produces a depolarization and an apparent conductance increase at the basolateral membrane (Hughes et al. 1988). By comparison, the present study shows that in isolated RPE cells of the bullfrog, cAMP caused a $10 \mathrm{mV}$ depolarization of the zero current potential and nearly a $50 \%$ increase in total membrane conductance. We conclude that the cAMP-activated $\mathrm{Cl}^{-}$ conductance is present on the basolateral membrane.

\section{Resting $\mathrm{Cl}^{-}$conductance}

Previous electrophysiological studies in the isolated RPE-choroid of bullfrog (la Cour, 1992) and toad (Fujii, Gallemore, Hughes \& Steinberg, 1992) provided evidence that in the unstimulated RPE the $\mathrm{Cl}^{-}$conductance accounts for 18 and 
$45 \%$, respectively, of the basolateral membrane conductance. In the present study, the resting membrane $\mathrm{Cl}^{-}$conductance of most cells was immeasurably small. For example, in the absence of cAMP or forskolin, the application of $\mathrm{Cl}^{-}$channel blockers, such as DIDS, which block the basolateral $\mathrm{Cl}^{-}$membrane conductance in the intact RPE (Fujii et al. 1992; Joseph \& Miller, 1991), generally had no effect on membrane conductance (not shown). Moreover, although decreases in extracellular $\mathrm{Cl}^{-}$concentration depolarized the membrane of some cells, indicating a finite $\mathrm{Cl}^{-}$ conductance (e.g. Fig. 3A), in most cells membrane hyperpolarizations were observed (not shown). The lack of a measurable $\mathrm{Cl}^{-}$conductance in most unstimulated single RPE cells precluded its characterization.

\section{Comparison to cAMP-activated $\mathrm{Cl}^{-}$conductances in other epithelia}

Preliminary studies indicate that bovine and human RPE express the gene product for the cystic fibrosis transmembrane regulator (CFTR) (Miller et al. 1992), a cAMP-regulated $\mathrm{Cl}^{-}$channel present in a number of secretory epithelia (Fuller \& Benos, 1992). Two features of the cAMP-activated $\mathrm{Cl}^{-}$conductance in amphibian RPE bear similarity to the CFTR $\mathrm{Cl}^{-}$channel : it has a linear $I-V$ relationship when symmetrical $\mathrm{Cl}^{-}$concentrations are present on the two sides of the membrane, and it is time independent. In other respects, however, the two channels appear to have important differences. For example, the anion permeability sequence typically reported for the wild-type CFTR channel is $\mathrm{Br}^{-} \geqslant \mathrm{Cl}^{-}>\mathrm{I}^{-}$(Anderson et al. 1991), whereas the anion selectivity sequence for the amphibian $\mathrm{RPE} \mathrm{Cl}^{-}$channel was $\mathrm{NO}_{3}^{-} \geqslant \mathrm{I}^{-}>\mathrm{Br}^{-}>\mathrm{Cl}^{-}$. Another difference is that the cAMP-regulated $\mathrm{Cl}^{-}$channel in the RPE was inhibited by DIDS whereas the $\mathrm{Cl}^{-}$channel implicated in cystic fibrosis is not (Cliff \& Frizzell, 1990; Anderson \& Welsh, 1991). Since the selectivity sequence and blocker sensitivity of the cAMP-activated $\mathrm{Cl}^{-}$conductance of the RPE resembles that of calcium-activated $\mathrm{Cl}^{-}$channels in other epithelia (Cliff \& Frizzell, 1990 ; Anderson \& Welsh, 1991), it is possible that the currents observed in this study were activated by a cAMP-induced increase in intracellular calcium. This possibility seems unlikely, however, in light of the fact that the addition of calcium ionophore A23187 to the bath had no effect on the membrane $\mathrm{Cl}^{-}$conductance (authors' unpublished observations).

\section{Physiological significance}

Under control conditions, the RPE actively transports $\mathrm{Cl}^{-}$in the retina-to-choroid (absorptive) direction (Miller \& Steinberg, 1977; Miller \& Farber, 1984; Hughes et al. 1987). The membrane events underlying this transport are thought to involve the uphill transport of $\mathrm{Cl}^{-}$into the cell across the apical membrane via a $\mathrm{Na}^{+}-\mathrm{K}^{+}-2 \mathrm{Cl}^{-}$ co-transporter (Kennedy, 1990; la Cour, 1992), its intracellular accumulation above the electrochemical potential for $\mathrm{Cl}^{-}$in the bathing solutions (Wiederholt \& Zadunaisky, 1984; la Cour, 1992), and its conductive exit across the basolateral membrane through a $\mathrm{Cl}^{-}$channel (Fujii et al. 1992; la Cour, 1992). By analogy to airway epithelia, where the rate of $\mathrm{Cl}^{-}$transport is stimulated by the activation of an apical $\mathrm{Cl}^{-}$channel (Welsh, 1987), one might expect cAMP to stimulate $\mathrm{Cl}^{-}$ absorption across the RPE, but in fact the reverse is true: cAMP inhibits active $\mathrm{Cl}^{-}$ absorption (Miller \& Farber, 1984). Although the reason for this inhibition is not 
known, it seems likely that cAMP affects other $\mathrm{Cl}^{-}$transport pathways in addition to the $\mathrm{Cl}^{-}$channel. For example, cAMP might inhibit the $\mathrm{Na}^{+}-\mathrm{K}^{+}-\mathrm{Cl}^{-}$co-transporter at the apical membrane, as suggested by la Cour (1992). Alternatively, the inhibition of $\mathrm{Cl}^{-}$absorption could arise from a cAMP-induced increase in the $\mathrm{Cl}^{-}$permeability of the paracellular pathway, as has been demonstrated in flounder intestine (Rao, Nash \& Field, 1984) or from the stimulation a $\mathrm{Cl}^{-}$secretory pathway, such as the one in the frog RPE that is activated by low $P_{\mathrm{CO}_{2}}$ and high extracellular $\mathrm{K}^{+}$(Edelman, Miller \& Hughes, 1988; Fong, Bialek, Hughes \& Miller, 1988).

What role, then, might an increase in the $\mathrm{Cl}^{-}$conductance of the basolateral membrane play in RPE transport? Preliminary studies suggest that the basolateral membrane of the bullfrog RPE contains a $\mathrm{Cl}^{-}-\mathrm{HCO}_{3}{ }^{-}$exchanger (Fong et al. 1988). An increase in $\mathrm{Cl}^{-}$conductance would increase $\mathrm{Cl}^{-}$efflux across this membrane, leading to a decrease in intracellular $\mathrm{Cl}^{-}$activity as has been observed with $\mathrm{Cl}^{-}$selective microelectrodes (B. A. Hughes \& S. S. Miller, unpublished observation). This intracellular $\mathrm{Cl}^{-}$activity decrease could in turn stimulate $\mathrm{HCO}_{3}{ }^{-}$efflux from the cell via the exchanger. If this hypothesis is correct, then one might expect cAMP to cause intracellular acidification and the stimulation of $\mathrm{HCO}_{3}{ }^{-}$absorption. A similar role for a cAMP-activated $\mathrm{Cl}^{-}$conductance in promoting $\mathrm{HCO}_{3}^{-}$efflux via a $\mathrm{Cl}^{-}-\mathrm{HCO}_{3}{ }^{-}$exchanger has been proposed for pancreatic duct cells (Gray, Greenwell \& Argent, 1988).

In summary, we postulate that the cAMP-activated conductance observed in isolated RPE cells corresponds to the basolateral membrane increase evoked by elevated cAMP levels in intact RPE, and may play a role in controlling the activity of the $\mathrm{Cl}^{-}-\mathrm{HCO}_{3}{ }^{-}$exchanger at that membrane.

We thank Michael Paterson for his assistance in a preliminary phase of this study and Dr Neil Richards for his helpful comments on this manuscript. This work was supported by NIH grants EYO8850 (B.A.H.) and EYO7003, a Research to Prevent Blindness Career Development Award (B.A.H.). Y.S. was supported in part by a Retinitis Pigmentosa Research Center Grant.

\section{REFERENCES}

Adorante, J. S. \& Miller, S. S. (1990). Potassium-dependent volume regulation in retinal pigment epithelium is mediated by Na, K, Cl cotransport. Journal of General Physiology 96, 1153-1176.

Anderson, M. P., Gregory, R. J., Thompson, S., Souza, D. W., Paul, S. R., Mulligan, C., Smith, A. E. \& WeLSh, M. J. (1991). Demonstration that CFTR is a chloride channel by alteration of its anion selectivity. Science 253, 202-205.

Anderson, M. P., \& Welsh, M. J. (1991). Calcium and cAMP activate different chloride channels in the apical membrane of normal and cystic fibrosis epithelia. Proceedings of the National Academy of Sciences of the USA, 88, 6003-6007.

Burnside, B. \& GarcIa, D. M. (1992). Inhibition of cAMP-induced pigment aggregation in green sunfish RPE by an organic anion transport inhibitor. Investigative Ophthalmology and Visual Science 33, 910.

ClifF, W. H. \& Frizzell, R. A. (1990). Separate $\mathrm{Cl}^{-}$conductances activated by cAMP and $\mathrm{Ca}^{2+}$ in $\mathrm{Cl}^{-}$-secreting epithelial cells. Proceedings of the National Academy of Sciences of the USA 87, 4956-4960.

Corey, D. P. \& Stevens, C. F. (1983). Science and technology of patch-recording electrodes. In Single-Channel Recording, ed. Sakmann, B. \& Neher, E., pp. 53-68. Plenum Press, New York. 
Edelman, J. L., Miller, S. S. \& Hughes, B. A. (1988). Regulation of chloride transport by frog retinal pigment epithelium. Proceedings of the International Congress of Eye Research 5, 51.

Evans, M. G. \& MarTY, A. (1986). Calcium-dependent chloride currents in isolated cells from rat lacrimal glands. Journal of Physiology 378, 437-460.

Fong, C. N., Bialek, S., Hughes, B. A. \& Miller, S. S. (1988). Basolateral membrane regulation of intracellular chloride activity in bullfrog retinal pigment epithelium. Proceedings of the International Congress of Eye Research 5, 51.

Fuji, S., Gallemore, R. P., Hughes, B. A. \& Steinberg, R. H. (1992). Direct evidence for a basolateral $\mathrm{Cl}^{-}$conductance in the toad retinal pigment epithelium. American Journal of Physiology 262, C374-383.

Fuller, C. M. \& Benos, D. J. (1992). CFTR! American Journal of Physiology 263, C267-287.

Gray, M. A., Greenwell, J. R. \& Argent, B. E. (1988). Secretin-regulated chloride channel on the apical plasma membrane of pancreatic duct cells. Journal of Membrane Biology 105, 131-142.

Hodgkin, A. L., McNaughton, P. A., Nunn, B. J. \& Y YU, K.-W. (1984). Effect of ions on retinal rods from Bufo marinus. Journal of Physiology 350, 649-680.

HoRn, R. \& MARTY, A. (1988). Muscarinic activation of ionic currents measured by a new wholecell recording method. Journal of General Physiology 92, 145-159.

Hughes, B. A., Adorante, J. S., Miller, S. S. \& Lin, H. (1989). Apical electrogenic $\mathrm{NaHCO}_{3}$ cotransport: a mechanism for $\mathrm{HCO}_{3}$ absorption across the retinal pigment epithelium. Journal of General Physiology 94, 125-150.

Hughes, B. A., Miller, S. S. \& Farber, D. B. (1987). Adenylate cyclase stimulation alters transport in frog retinal pigment epithelium. American Journal of Physiology 252, C385-395.

Hughes, D. A., Miller, S. S., Joseph, D. P. \& Edelman, J. (1988). Cyclic AMP stimulates the $\mathrm{Na}^{+} / \mathrm{K}^{+}$pump in the frog retinal pigment epithelium. American Journal of Physiology 254, C84-98.

Hughes, B. A., Miller, S. S. \& Machen, T. E. (1984). Effects of cyclic AMP on fluid absorption and ion transport across frog retinal pigment epithelium. Measurements in the open-circuit state. Journal of General Physiology 83, 875-899.

Hughes, B. A. \& Paterson, M. (1991). cAMP activates a $\mathrm{Cl}^{-}$conductance in single retinal pigment epithelial cells of the bullfrog. Investigative Ophthalmology and Visual Science 32, 836.

Hughes, B. A. \& SEGAwA, Y. (1992). Characterization of the cAMP-activated chloride conductance in the amphibian RPE. Investigative Ophthalmology and Visual Science 33, 913.

Hughes, B. A. \& Steinberg, R. H. (1990). Voltage-dependent currents in isolated cells of the frog retinal pigment epithelium. Journal of Physiology 428, 273-297.

JosePh, D. P. \& Miller, S. S. (1991). Apical and basal membrane ion transport mechanisms in bovine retinal pigment epithelium. Journal of Physiology 435, 439-463.

KENNEDY, B. G. (1990) $\mathrm{Na}^{+}-\mathrm{K}^{+}-\mathrm{Cl}^{-}$cotransport in cultured cells derived from human retinal pigment epithelium. American Journal of Physiology 259, C29-34.

LA COUR, M. (1992). $\mathrm{Cl}^{-}$transport in frog retinal pigment epithelium. Experimental Eye Research 54, 921-931.

Marmor, M. F. (1989). Mechanisms of normal retinal adhesion. In Retina, vol. 3, ed. GLASER, B. M. \& Michaels, R. G., pp. 71-87. C.V. Mosby Co., St Louis, MO, USA.

Miller, S. S. \& Edelman, J. L. (1990). Active ion transport pathways in the bovine retinal pigment epithelium. Journal of Physiology 424, 283-300.

MILLER, S. S. \& FARBER, D. (1984). Cyclic AMP modulation of ion transport across frog retinal pigment epithelium. Measurements in the short-circuit state. Journal of General Physiology 83, 853-874.

Miller, S. S., Ravin, J., Strong, T., Iannuzzi, M., Adams, A., Colins, F., Reenstra, W. \& McCray, P. JR (1992). Cystic fibrosis (CF) gene product is expressed in retina and retinal pigment epithelium. Investigative Ophthalmology and Visual Science 33, 1009.

Miller, S. S. \& Steinbera, R. H. (1977). Passive ionic properties of frog retinal pigment epithelium. Journal of Membrane Biology 36, 337-372.

Pacaud, P., Loirand, G., Lavie, J. L., Mironneau, C. \& Mironneau, J. (1989). Calciumactivated chloride current in rat vascular smooth muscle cells in short term primary culture. Pflügers Archiv 413, 629-636.

RAE, J. L. \& CoOPER, K. (1990). New techniques for the study of lens electrophysiology. Experimental Eye Research 50, 603-614. 
RAO, M. C., NASh, N. T. \& FieLd, M. (1984). Differing effects of cGMP and cAMP on ion transport across flounder intestine. American Journal of Physiology 246, C167-171.

WELSh, M. J. (1987). Electrolyte transport by airway epithelia. Physiological Reviews 67, 1143-1184.

Wiederholt, M. \& Zadunaisky, J. A. (1984). Decrease of intracellular chloride activity by furosemide in frog retinal pigment epithelium. Current Eye Research 3, 673-675. 